\title{
PENGARUH BIAYA BAHAN BAKU TERHADAP PENJUALAN BERSIH PADA PT INDOFOOD CBP SUKSES MAKMUR TBK
}

\author{
${ }^{1}$ Rukmi Juwita, ${ }^{2}$ Asyifa Rizcha Puspita \\ Program Studi D4 Akuntansi Keuangan \\ Politeknik Pos Indonesia \\ rukmijuwita@poltekpos.ac.id, asyifarizchapuspita18@gmail.com
}

\begin{abstract}
ABSTRAK
PT Indofood CBP Sukses Makmur Tbk bermarkas di Jakarta, Indonesia, sebagai produsen berbagai jenis makanan dan minuman. Jika dilihat dari fenomena atau masalah yang ada pada saat ini banyak faktor yang mempengaruhi penurunan dari penjualan suatu perusahaan, maka dari itu penelitian ini bertujuan untuk mengetahui pengaruh dari biaya bahan baku terhadap penjualan bersih yang terjadi di PT Indofood CBP Sukses Makmur Tbk. Karena biaya bahan baku merupakan komponen utama di perusahaan dan berkaitan erat dalam peningkatan penjualan. Data yang digunakan yaitu data sekunder. Serta alat uji yang digunakan adalah analisis korelasi product moment, analisis regresi linier sederhana, koefisien determinasi, dan uji T. Dalam uji koefisien determinasi menghasilkan biaya bahan baku berpengaruh sebesar $93,8 \%$ terhadap penjualan bersih dan sisanya dipenngaruhi oleh variabel lain. Dari hasil pengujian uji t menghasilkan thitung 23,918> ttabel 1,684 yang mana dapat disimpulkan bahwa terdapat pengaruh yang positif antara biaya bahan baku terhadap penjualan bersih.
\end{abstract}

Kata kunci: Biaya bahan baku, dan penjualan

ABSTRACT

PT Indofood CBP Sukses Makmur Tbk is headquartered in Jakarta, Indonesia, as a producer of various types of food and beverages. We can see from the current phenomenon or problem, many factors affect the decline in sales of a company, therefore this study aims to determine the effect of raw material costs on net sales that occur at PT Indofood CBP Sukses Makmur Tbk. Because the cost of raw materials is a major component in the company and is closely related to increased sales. The data used are secondary data. The test tool used is the product moment correlation analysis, simple linear regression analysis, the coefficient of determination, and the $t$ test. In the coefficient of determination test, the cost of raw materials has an effect of $93.8 \%$ on net sales and the rest is influenced by other variables. From the t test results on t count 23.918> t table 1.684, it can be concluded that there is a positive influence between the cost of raw materials on net sales.

\section{Keywords: Raw material costs, and sales}

\section{PENDAHULUAN}

Perusahaan makanan dan minuman merupakan perusahaan yang bergerak di bidang pembuatan produk kemudian dijual guna memperoleh keuntungan ataupun laba. Untuk mencapai tujuan tersebut perusahan akan melakukan berbagai cara agar penjualan perusahaan meningkat. Dikutip dari (Dirgantara, 2020) Kontan.id - JAKARTA. "Di tengah persebaran virus corona, PT Mayora Indah Tbk (MYOR) mengalami penurunan penjualan sebesar $10,55 \%$. mencatatkan penjualan hingga Rp 5,38 triliun di kuartal I2020, jika dibandingkan penjualan kuartal I-2019 yang mencapai Rp 6,01 triliun. Analis RHB Sekuritas Michael Wilson Setjoadi menuturkan penurunan penjualan MYOR tidak terlepas dari anjloknya jumlah penjualan ekspor. Merujuk laporan keuangan MYOR, penjualan ekspor MYOR merosot 32,15\% year on year (yoy), dari Rp 2,4 triliun pada kuartal I-2019 menjadi Rp 1,63 triliun pada kuartal I-2020. "Hal ini dikarenakan pasar ekspor MYOR di luar negeri, khususnya China menetapkan kebijakan lockdown. Pada akhirnya menghambat penjualan ekspor MYOR walau dari dalam negeri justru 
mengalami peningkatan," ujar Michael kepada Kontan.co.id". Berikut gambaran penurunan penjualan yang terjadi di PT Mayora Indah Tbk (MYOR), yaitu:

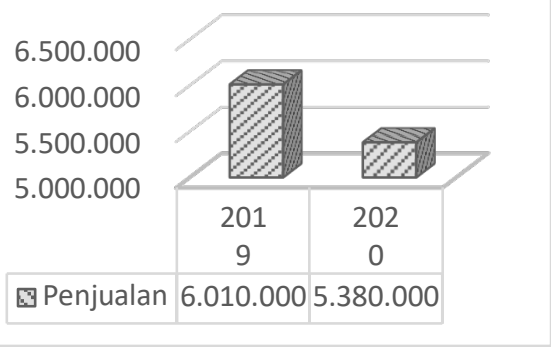

Gambar 1

Grafik Penurunan Penjualan kuartal I 2020 PT Mayora Indah Tbk (MYOR)

Selai itu, dikutip juga dari (Ayuningtyas, 2019) Jakarta, CNBC Indonesia, mengatakan bahwa "Menilik perincian pemasukan dari setiap segmen usaha perusahaan, hanya segmen usaha minuman yang mencatatkan penurunan penjualan $0,34 \%$ YoY, dari Rp 1,47 triliun menjadi Rp 1,46 triliun. Segmen minuman ICBP memang sejak tahun lalu menghadapi kompetisi yang cukup ketat. Belum lagi, anak usaha perusahaan, yakni PT Anugerah Indofood Barokah Makmur (AIBM), yang selama ini mendapatkan hak eksklusif untuk memproduksi, mendistribusikan, dan menjual produk minuman Pepsi diketahui telah mengakhiri kontrak kerja sama dengan PepsiCO Inc (PepsiCO).

Dalam pernyataan resminya (4/10/2019), manajemen anak usaha PT Indofood Sukses Makmur Tbk (INDF) ini menyampaikan, perjanjian EBA (Exclusive Bottling Agreement) antara AIBM dengan PepsiCO tidak dilanjutkan karena alasan komersial, di mana kontrak berakhir pada Oktober 2019. PT Indofood CBP Sukses Makmur Tbk mengalami penurunan penjualan dalam segmen minuman pada periode september 2019. Sebagai gambaran dapat dilihat pada data penjualan dalam Laporan Keuangan PT Indofood CBP Sukses Makmur Tbk periode triwulan 2017-2019 berikut ini:

Tabel 1. Penjualan Segmen Minuman PT Indofood CBP Sukses Makmur Tbk Triwulan 2017-2019

\begin{tabular}{|c|c|c|c|c|}
\hline \multirow{2}{*}{ Periode } & \multicolumn{2}{|c|}{ Tahun } & Perubahan & $\begin{array}{c}\text { Persentase } \\
\text { Perubahan }\end{array}$ \\
\cline { 2 - 3 } & $\mathbf{2 0 1 8}$ & $\mathbf{2 0 1 9}$ & & $8,875 \%$ \\
\hline Triwulan I & 416.923 & 453.925 & 37.002 & $3,200 \%$ \\
\hline Triwulan II & 945.393 & 975.649 & 30.256 & $3,0.34 \%$ \\
\hline Triwulan III & $\mathbf{1 . 4 6 7 . 6 2 7}$ & $\mathbf{1 . 4 6 2 . 6 0 7}$ & $\mathbf{( 5 . 0 2 0 )}$ & $\mathbf{- 0 , 3 4 2 \%}$ \\
\hline Triwulan IV & 1.832 .344 & 1.884 .228 & 51.884 & $2,832 \%$ \\
\hline
\end{tabular}

Sumber: $w$ ww.indofood.com, diolah sendiri

Dapat dilihat dari fenomena yang terjadi pada dua perusahaan makanan dan minuman diatas bahwa di PT Mayora Indah Tbk (MYOR) mengalami penurunan penjualan pada kuartal I tahun 2020 sebesar 10,54\% dibandingkan tahun sebelumnya. Begitupula yang terjadi pada penjualan PT Indofood CBP Sukses Makmur Tbk mengalami penurunan pada triwulan ke 3 yaitu turun sebanyak $0,341 \%$ dari tahun sebelumnya. Dalam pengendalian naik atas turunnya penjualan biasanya dikarenakan dengan daya beli masyarakat yang kurang. Tapi tidak hanya itu, naik turunnya penjualan juga bisa disebabkan oleh faktor lain. Dalam hal ini perlu diperhatikan juga biaya-biaya yang dikeluarkan perusahaan. Menurut (Sugiarti, 2018), menjelaskan bahwa "Biaya bahan baku dan biaya tenaga kerja langsung merupakan dua komponen utama perusahaan dalam menjalankan usahanya. Dua komponen tersebut dalam hal bisnis sangat erat kaitannya dengan penjualan dan laba yang didapatkan oleh perusahaan". Apalagi jika 
dilihat dengan keadaan saat ini, dimana harga bahan baku yang semakin meningkat dikarenakan inflasi ataupun wabah covid-19, dapat mempengaruhi harga dari suatu produk sehingga berpengaruh pada daya beli masyarakat secara tidak langsung akan berpengaruh pada penjualan itu sendiri juga. Dapat dilihat dari penelitian terdahulu atau studi empiris yang ada berikut ini.

Penelitian yang dilakukan oleh (Sugiarti, 2018) yang berjudul "Pengaruh Biaya Bahan Baku Dan Biaya Tenaga Kerja Langsung Terhadap Penjualan Bersih Pada PT Mustika Ratu Tbk menyimpulkan bahwa biaya bahan baku berpengaruh signifikan terhadap penjualan bersih pada PT Mustika Ratu Tbk, dan secara simultan hal tersebut menunjukkan bahwa biaya bahan baku dan biaya tenaga kerja langsung berpengaruh signifikan terhadap penjualan bersih pada PT Mustika Ratu Tbk".

Kemudian penelitian yang dilakukan oleh (Wulandari, 2015) yang berjudul "Pengaruh Biaya Produksi Terhadap Hasil Penjualan Pupuk Petroganik Pada CV. Ijo Ngawi dengan hasil menunjukkan bahwa biaya bahan baku berpengaruh positif dan signifikan terhadap hasil penjualan pupuk petroganik pada CV Ijo Ngawi. Biaya tenaga kerja berpengaruh positif dan signifikan terhadap hasil penjualan pupuk petroganik pada CV Ijo Ngawi. Biaya overhead pabrik secara parsial tidak berpengaruh signifikan terhadap hasil penjualan pupuk petroganik pada CV Ijo Ngawi. Secara bersama-sama variabel biaya bahan baku, biaya tenaga kerja, dan biaya overhead pabrik berpengaruh terhadap hasil penjualan pupuk petroganik pada CV Ijo Ngawi". Penelitian yang dilakukan oleh Rogi Gusrizaldi \& Eka Komalasari (2016) dengan judul "Analisis FaktorFaktor Yang Mempengaruhi Tingkat Penjualan Di Indrako Swalayan Teluk Kuantan, yang menghasilkan dari masing-masing indikator lebih condong untuk mempengaruhi ke tingkat penjualan"

Pada penelitian yang dilakukan oleh (Hartanti, 2016) yang berjudul "Pengaruh Biaya Produksi Terhadap Penjualan Pada PT Shindengen Indonesia hasil penelitian menunjukkan bahwa terdapat hubungan yang sangat kuat dan terdapat pengaruh yang signifikan antara biaya produksi dengan hasil penjualan". Penelitian menurut Sry Rahayu Febriani (2016) yang berjudul, "The Impact Analysis Of Raw Material Price On Firm Survival, menghasilkan harga input impor ditemukan secara signifikan mempengaruhi kemampuan perusahaan untuk bertahan hidup. Perkecil kemungkinan perusahaan untuk bertahan karena harga kenaikan pada bahan baku impor menjelaskan bahwa penggunaan bahan baku impor masih menjadi masalah di industri manufaktur".

Penelitian berikut dilakukan oleh Hadi Moheb-Alizadeh \& Robert Handfield (2018) dengan judul "The Impact of Raw Materials Price Volatility on Cost of Goods Sold (COGS) for Product Manufacturing (Dampak Volatilitas Harga Bahan Baku terhadap Harga Pokok Penjualan (COGS) untuk Pembuatan Produk) menyimpulkan bahwa dampak fluktuasi harga bahan baku di tingkat kedua aliran materi di perusahaan COGS diintensifkan oleh perubahan harga yang saling terkait bahan baku, yang memiliki pengaruh spesifik pada COGS perusahaan. Karenanya, COGS perusahaan menjadi jauh sensitif terhadap fluktuasi harga bahan baku yang saling terkait. Oleh karena itu, perlu waspada tentang volatilitas agar untuk menjadi kuat melawannya. Namun, kami melihat bahwa tidak ada hubungan timbal balik apapun di antara harga bahan baku di tingkat pertama aliran material. Ini menyiratkan bahwa setiap fluktuasi dalam perusahaan COGS semata-mata merupakan dampak dari volatilitas harga bahan mentah tersebut bahan".

\section{Identifikasi Masalah}

Berdasarkan uraian yang telah dijabarkan diatas, maka penulis memutuskan identifikasi masalah sebagai berikut:

1. Bagaimana biaya bahan baku pada PT Indofood CBP Sukses Makmur Tbk?

2. Bagaimana penjualan bersih pada PT Indofood CBP Sukses Makmur Tbk? 
3. Bagaimana pengaruh biaya bahan baku terhadap penjualan bersih pada PT Indofood CBP Sukses Makmur Tbk ?

\section{KAJIAN PUSTAKA}

Menurut (Sujarweni, 2019), "Bahan baku mempunyai definisi bahan-bahan yang merupakan komponen utama yang membentuk keseluruhan dari produk jadi”. Sedangkan variabel y yang digunakan dalam penelitian ini yaitu penjualan bersih. Penjualan bersih menurut (Mulyadi, 2015) adalah "Penjualan (pada nilai faktur) dikurangi dengan pengembalian, pengurangan harga, biaya transport yang dibayar untuk langganan dan potongan penjualan yang diambil". Menurut Sugiarti (2018) menjelaskan tentang kaitannya biaya bahan baku dengan penjualan menurutnya secara garis besar biaya. "Biaya bahan baku dan biaya tenaga kerja langsung merupakan dua komponen utama perusahaan dalam menjalankan usahanya. Dua komponen tersebut dalam hal bisnis sangat erat kaitannya dengan penjualan dan laba yang didapatkan oleh perusahaan".

\section{METODE PENELITIAN}

Metode penelitian yang digunakan dalam penelitian ini merupakan metode kuantitatif asosiatif yang bersifat kausal. Dari pengertiannya metode penelitian kuantitatif menurut (Sugiyono, 2019), "Metode penelitian kuantitatif yaitu metode penelitian yang berlandaskan pada filsavat positivisme, digunakan untuk meneliti pada populasi atau sampel tertentu, pengumpulan data menggunakan instrumen penelitian, data penelitian berupa angka-angka dan analisis menggunakan statistik, dengan tujuan untuk menggambarkan dan menguji hipotesis yang telah ditetapkan".

Menurut (Sugiyono, 2019), menyatakan bahwa "Asosiatif merupakan suatu penelitian yang bermaksud menggambarkan dan menguji hipotesis hubungan dua variabel atau lebih". "Kausal adalah hubungan yang bersifat sebab akibat. Jadi disini ada variabel independen (variabel yang mempengaruhi) dan dependen (dipengaruhi)". (Sugiyono, 2019). Jadi dalam penelitian ini menggunakan metode kuantitatif asosiatif yang bersifat kausal karena penelitian ini berupa angka-angka dan mencari hubungan sebab akibat atau pengaruh dari dua variabel yaitu variabel X (biaya bahan baku) dan variabel Y (penjualan bersih) yang perhitungannya menggunakan IBM SPSS statistics 25.

Teknik pengumpulan data yang digunakan dalam penelitian ini adalah studi kepustakaan (library research) dan dokumentasi. Menurut (Juwita \& Satria, 2017), "Studi kepustakaan (library research) yaitu merupakan metode pengumpulan kepustakaan yang dilakukan dengan cara mempelajari, meneliti dan menelaah buku-buku referensi, catatan kuliah dan buku-buku lain yang ada kaitannya dengan cakupan judul yang diambil". Studi dokumentasi adalah cara pengumpulan data melalui pencatatan dan menyelidiki terhadap dokumen-dokumen yang ada pada objek pengumpulan data dengan cara mengumpulkan, mencatat dan menghitung data/dokumen yang berkaitan dengan permasalahan yang diteliti.

Teknik sampling dalam penelitian ini menggunakan nonprobability sampling dan teknik pengambilan sampel yang digunakan adalah sampling purposive. Menurut (Sugiyono, 2019) menjelaskan mengenai pengertian nonprobability sampling yaitu "Teknik pengambilan sampel yang tidak memberi peluang/kesempatan sama bagi setiap unsur atau anggota populasi untuk dipilih menjadi sampel". "Sampling purposive adalah teknik penentuan sampel dengan pertimbangan tertentu". (Sugiyono, 2019).

\section{Analisis Korelasi Product Moment}

Menurut (Sugiyono, 2019), menjelaskan bahwa "Korelasi Product Moment digunakan untuk menguji hipotesis hubungan antara satu variabel independen dengan satu variabel dependen". Sehingga analisis ini digunakan untuk melihat seberapa kuat hubungan satu variabel independen (biaya bahan baku) dengan satu variabel dependen (penjualan bersih). 


\section{Analisis Regresi Linier Berganda}

Menurut (Sugiyono, 2019), menjelaskan bahwa "Regresi digunakan untuk memprediksi nilai variabel dependen berdasarkan nilai variabel independen. Analisis regresi dilakukan jika hubungan dua variabel berupa hubungan kausal atau fungsional".

\section{Koefisien Determinasi}

Menurut Duwi Priyatno dalam (Wulandari, 2015), menyebutkan bahwa "Analisis koefisien determinasi digunakan untuk mengetahui seberapa besar prosentase sumbangan pengaruh variabel independen secara serentak terhadap variabel dependen. Dalam koefisien determinasi dapat dilihat berapa persen pengaruh antara biaya bahan baku terhadap penjualan bersih. Koefiseien determinasi memiliki persentase $100 \%$. Apabila tidak $100 \%$, maka selisih dari persentase $100 \%$ merupakan pengaruh faktor lainnya yang mempengaruhi penjualan.

Uji t

Uji t sering juga dikenal sebagai uji parsial, yaitu untuk menguji bagaimana pengaruh masing-masing variabel bebasnya secara sendiri-sendiri terhadap variabel terikatnya. Jika dalam penelitian ini dapat dilihat pengaruh biaya bahan baku terhadap penjualan bersihnya.

\section{HASIL DAN PEMBAHASAN \\ Hasil Penelitian \\ Analisis Korelasi Product Moment}

Pengujian Analisis Korelasi Product Moment digunakan untuk mengetahui kuat atau lemahnya hubungan antara biaya bahan baku terhadap penjualan bersih. Dalam alat uji ini akan menggunakan IBM SPSS Statistic 25.

Tabel 2. Analisis Korelasi Product Moment

\begin{tabular}{|c|c|c|c|}
\hline \multicolumn{4}{|c|}{ Correlations } \\
\hline & & \multicolumn{2}{|c|}{ Biaya Bahan BakuPenjualan Bersih } \\
\hline \multirow{3}{*}{ Biaya Bahan Baku } & Pearson Correlation & 1 & $968^{* *}$ \\
\hline & Sig. (1-tailed) & &, 000 \\
\hline & $\mathrm{N}$ & 40 & 40 \\
\hline \multirow[t]{3}{*}{ Penjualan Bersih } & Pearson Correlation & $968^{* *}$ & 1 \\
\hline & Sig. (1-tailed) &, 000 & \\
\hline & $\mathrm{N}$ & 40 & 40 \\
\hline
\end{tabular}

Dapat dilihat dari hasil pengujian analisis korelasi product moment diatas, maka didapatkan hasil $\mathrm{R}_{\text {hitung }}$ sebesar 0,968 dan $\mathrm{R}_{\text {tabel }}$ sebesar 0,312. Jadi dapat disimpulkan bahwa $R_{\text {hitung }} 0,968>R_{\text {tabel }} 0,312$, yang berarti bahwa terdapat hubungan antara biaya bahan baku terhadap penjualan bersih. Jika dilihat dari hasil $\mathrm{R}_{\text {hitung, maka biaya bahan }}$ baku terhadap penjualan PT Indofood CBP Sukses Makmur TBk berada pada interpretasi 0,80-1,00, yang memiliki arti bahwa biaya bahan baku terhadap penjualan bersih memiliki hubungan yang sangat kuat. Berdasarkan hal tersebut, dapat disimpulkan bahwa terdapat hubungan yang sangat kuat antara biaya bahan baku terhadap penjualan bersih. Jadi, dari hasil tersebut menunjukan bahwa biaya bahan baku di PT Indofood CBP Sukses Makmur Tbk memiliki hubungan yang sangat kuat terhadap penjualannya.

\section{Analisis Regresi Linier Berganda}

Dalam pengujian analisis linier sederhana digunakan untuk mengetahui pengaruh biaya bahan baku terhadap penjualan bersih, yang mana dalam pengujiannya akan digunakan aplikasi IBM SPSS Statistic 25. Berikut merupakan tabel analisis regresi linier sederhana yang telah diolah:

\section{Tabel 3. Analisis Regresi Linier Sederhana}




\begin{tabular}{|c|c|c|c|c|c|}
\hline \multicolumn{6}{|c|}{ Coefficients $^{\mathrm{a}}$} \\
\hline \multirow[b]{2}{*}{ Model } & \multicolumn{2}{|c|}{ Unstandardized Coefficients } & \multirow{2}{*}{$\begin{array}{c}\begin{array}{c}\text { Standardized } \\
\text { Coefficients }\end{array} \\
\text { Beta }\end{array}$} & \multirow[b]{2}{*}{$\mathrm{t}$} & \multirow[b]{2}{*}{ Sig. } \\
\hline & $\mathrm{B}$ & Std. Error & & & \\
\hline \begin{tabular}{l|l}
1 & (Constant)
\end{tabular} & $-2092407,959$ & 405770,524 & & $-5,157$ &, 000 \\
\hline Biaya Bahan Baku & 2,350 &, 098 & ,968 & 23,918 &, 000 \\
\hline
\end{tabular}

Sumber: data diolah sendiri menggunakan IBM SPSS Statistic 25

Dapat dilihat dari tabel diatas, hasil yang didapatkan dari analisis regresi linier sederhana nilai konstanta sebesar $-2092407,959$ dan nilai regresinya sebesar 2,350. Sehingga jika nilai tersebut dimasukan ke dalam rumus regresi linier sederhana akan menghasilkan sebagai berikut:

$$
Y=-2092407,959+2,350 X
$$

Keterangan:

$\mathrm{X}$ : Biaya bahan baku

$\mathrm{Y}$ : Penjualan bersih

Berdasarkan persamaan yang disajikan diatas, dapat diketahui bahwa konstanta (a) bernilai -2092407,959 yang berarti bahwa jika biaya bahan baku bernilai nol maka penjualan bersih yang didapatkan sebesar -2092407,959, sehingga dapat di interpretasikan bahwa jika tidak ada biaya bahan baku maka tidak akan ada penjualan bersih. Dalam persamaan tersebut juga dapat diketahui bahwasanya setiap adanya kenaikan biaya bahan baku sebanyak 1 satuan, maka akan menambah penjualan bersih sebesar 2,350 satuan. Jadi, apabila biaya bahan bakunya bertambah atau naik 1 satua, maka pejualan bersihnya juga akan bertambah sebesar 2,350 satuan.

\section{Koefisien Determinasi}

Untuk mengetahui derajat (persentase) ketergantungan atau determinasi antara variabel biaya bahan baku $(\mathrm{X})$ terhadap variabel penjualan bersih $(\mathrm{Y})$, maka digunakan analisis koefisien determinasi dalam mencarinya. Hasil dari koefisien determinasi dapat dilihat dari tabel berikut ini:

Tabel 4. Analisis koefisien determinasi

\begin{tabular}{|l|r|r|r|r|}
\hline \multicolumn{5}{|c|}{ Model Summary } \\
\hline Model & $\mathrm{R}$ & R Square & Adjusted R Square & Std. Error of the Estimate \\
\hline 1 &, $968^{\mathrm{a}}$ &, 938 &, 936 & 515602,566 \\
\hline a. Predictors: (Constant), Biaya Bahan Baku \\
\hline \multicolumn{4}{|c|}{ Sumber: data diolah sendiri menggunakan IBM SPSS Statistic 25 }
\end{tabular}

Dapat dilihat dari hasil perhitungan diatas, dapat diketahui bahwa koefisien determinasi memiliki nilai $0,968^{2}$ dan $\mathrm{R}_{\text {square }}$ sebesar 0,938 atau $93,8 \%$; Berdasarkan tabel diatas maka dapat di interpretasikan bahwa biaya bahan baku dapat mempengaruhi penjualan bersih sebesar $93,8 \%$, dan sisanya sebanyak 0,062 atau $6,2 \%$ dari penjualan bersih dipengaruhi oleh faktor lain yang tidak dimasukkan didalam penelitian ini.

Uji t

Dapat dilihat tabel hasil perhitungan analisis uji t yang sudah diolah menggunakan aplikasi IBM SPSS Statistic 25, sebagai berikut:

Tabel 5. Analisis Uji t

\begin{tabular}{|l|c|c|c|c|c|}
\hline \multicolumn{7}{|c|}{ Coefficients $^{\mathbf{a}}$} \\
\hline \multirow{2}{*}{ Model } & \multicolumn{7}{|c|}{$\begin{array}{c}\text { Standardized } \\
\text { Coefficients }\end{array}$} & & \\
\cline { 2 - 5 } & Unstandardized Coefficients & B & Std. Error & Beta & Sig. \\
\hline 1 & (Constant) & $-2092407,959$ & 405770,524 & & $-5,157,000$ \\
\hline
\end{tabular}




\begin{tabular}{|l|l|l|l|l|l|}
\hline $\begin{array}{l}\text { Biaya Bahan } \\
\text { Baku }\end{array}$ & 2,350 &, 098 &, 968 & 23,918 &, 000 \\
\hline
\end{tabular}

Sumber: data diolah sendiri menggunakan IBM SPSS Statistic 25

Dalam uji t terdapat beberapa kriteria yang digunakan untuk penerimaan hipotesis dalam penelitian, yaitu sebagai berikut:

a. Jika $t_{\text {hitung }}>t_{\text {tabel, }}$, maka Ha diterima dan Ho ditolak

b. Jika $t_{\text {hitung }} \leq \mathrm{t}_{\text {tabel, }}$, maka Ha ditolak dan Ho diterima

Jika dilihat dari tabel hasil perhitungan uji $\mathrm{t}$ diatas, dapat diketahui nilai $\mathrm{t}_{\text {hitung }}$ sebesar 23,918. Jika dikaitkan dengan nilai $t_{\text {tabel, }}$ harus diketahui nilai derajat kebebasannya (df). Sehingga derajat kebebasan $(\mathrm{df})=\mathrm{n}-\mathrm{k}(40-2)$ sebesar 38 dan didapatkan tabel sebesar 1,684. Berdasarkan hal tersebut, dapat diketahui $t_{\text {hitung }} 23,918>\mathrm{t}_{\text {tabel }} 1,684$ dan jika dilihat dari tabel analisis uji t (tabel 5), maka dapat diketahui angka signifikansi sebesar 0,000, dimana $0,000<0,05$ yang berarti terdapat pengaruh yang signifikan antara biaya bahan baku terhadap penjualan bersih pada PT Indofood CBP Sukses Makmur Tbk. Sehingga dapat disimpulkan bahwa Ha diterima dan Ho ditolak, yang berarti terdapat pengaruh positif yang signifikan antara biaya bahan baku terhadap penjualan bersih pada PT Indofood CBP Sukses Makmur Tbk. Jadi, dari hasil uji t tersebut dapat di interpretasikan bahwa biaya bahan baku sangat berpengaruh positif dan juga signifikan terhadap penjualan bersih di PT Indofood CBP Sukses Makmur Tbk.

\section{Pembahasan Penelitian}

\section{Biaya Bahan Baku pada PT Indofood CBp Sukses Makmur TBK}

PT Indofood CBP Sukses Makmur tahun 2010-2019 mengalami kenaikan dan penurunan dari tahun ketahun per triwulan. Pada triwulan I, PT Indofood CBP Sukses Makmur Tbk selama tahun 2010-2019 mengeluarkan biaya bahan baku tertinggi pada tahun 2019 sebesar Rp. 5.822.811.000.000 (Rp. 5,8 triliun) dan pengeluaran terendah yaitu Rp. 2.710.181.000.000 (Rp. 2,7 triliun) pada tahun 2010. Selain itu pada triwulan ke II, PT Indofood CBP Sukses Makmur Tbk mengalami pengeluaran biaya bahan baku tertinggi pada tahun 2019 sebesar Rp. 5.004.407.000.000 (Rp. 5,4 triliun), juga mengalami pengeluaran terkecil sebesar Rp. 2.710.172.000.000 (Rp.2,7 triliun) pada tahun 2010.

Selanjutnya pada triwulan ke III, PT Indofood CBP Sukses Makmur Tbk mengeluarkan biaya bahan baku dengan pengeluaran terbesar sebesar Rp. 5.558.057.000.000 (Rp. 5,5 triliun) terjadi pada tahun 2019 dan pengeluaran biaya bahan baku terendah terjadi pada tahun 2010 sebesar Rp. 2.883.827.000.000 (Rp. 2,8 triliun). Pada triwulan ke 4, yang terjadi pada PT Indofood CBP Sukses Makmur yaitu mengalami pengeluaran biaya bahan baku terbesar pada tahun 2018 yaitu sebesar Rp. 5.242.368.000.000 (Rp. 5,2 triliun) dan mengalami pengeluaran terkecil pada tahun 2010 sebesar Rp. 2.633.277.000.000 (Rp. 2,6 triliun). Jika dilihat secara keseluruhan maka pengeluaran biaya bahan baku yang dikeluarkan oleh PT Indofood CBP Sukses Makmur Tbk paling besar terjadi pada tahun 2019 triwulan ke 1 sebesar Rp. 5.822.811.000.000 (Rp. 5,8 triliun) dan pengeluaran biaya bahan baku pada PT Indofood CBP Sukses Makmur Tbk selama tahun 2010-2019 terendah terjadi pada tahun 2010 triwulan ke 4 sebesar Rp. 2.633.277.000.000 (Rp. 2,6 triliun).

Hal tersebut sesuai dengan konsep teori yang dipaparkan (Sujarweni, 2019), yaitu "Bahan baku mempunyai definisi bahan-bahan yang merupakan komponen utama yang membentuk keseluruhan dari produk jadi", dan juga (Sujarweni, 2019) mengungkapkan bahwa "unsur dari biaya bahan baku yang dibeli terdiri dari biaya pembelian, biaya yang berkaitan dengan pembelian (biaya angkut), dan biaya yang dikeluarkan hingga bahan baku siap diolah". Yang dimana komponen-komponen atau unsur tersebut merupakan 
keseluruhan atau jumlah dari biaya bahan baku yang digunakan oleh PT Indofood CBP Sukses Makmu Tbk. Dalam biaya pembelian yang dikeluarkan biasanya biaya yang tercantum didalam faktur pembelian bahan baku. Contoh jika dalam pembuatan mie maka yang masuk dalam biaya pembelian adalah biaya yang dikeluarkan saat membeli tepung terigu, tapioka, air, garam, dan minyak goreng sebagai bahan utama pembuatan mie.

\section{Penjualan Bersih pada PT Indofood CBP Sukses Makmur Tbk}

PT Indofood CBP Sukses Makmur mengalami kenaikan dan penurunan penjualan bersih dari tahun 2010-2019. Pada triwulan I, PT Indofood CBP Sukses Makmur Tbk selama tahun 2010-2019 mememperoleh penjualan bersih tertinggi pada tahun 2019 sebesar Rp. 11.255.645.000.000 (Rp. 11,2 triliun) dan pemasukan terendah yaitu Rp. 4.336.503.000.000 (Rp. 4,3 triliun) pada tahun 2010. Selain itu, pada triwulan ke II, PT Indofood CBP Sukses Makmur Tbk mengalami perolehan penjualan bersih tertinggi terjadi pada tahun 2019 sebesar Rp. 10.874.459.000.000 (Rp. 10,8 triliun), juga mengalami pemasukan terkecil sebesar Rp. 4.581.556.000.000 (Rp. 4,5 triliun) pada tahun 2010. Selanjutnya pada triwulan ke III, PT Indofood CBP Sukses Makmur Tbk memperoleh penjualan bersih dengan pemasukan terbesar sebesar Rp. 10.660.235.000.000 (Rp. 10,6 triliun) terjadi pada tahun 2019 dan perolehan penjualan bersih terendah terjadi pada tahun 2010 sebesar Rp. 4.647.341.000.000 (Rp. 4,6 triliun).

Pada triwulan ke 4, yang terjadi pada PT Indofood CBP Sukses Makmur yaitu mengalami perolehan penjualan bersih terbesar pada tahun 2019 yaitu sebesar Rp. 9.506.364.000.000 (Rp. 9,5 triliun) dan memperoleh penjualan bersih terkecil pada tahun 2010 sebesar Rp. 4.336.503.000.000 (Rp. 4,3 triliun). Jika dilihat secara keseluruhan maka penjualan bersih yang diperoleh PT Indofood CBP Sukses Makmur Tbk paling besar terjadi pada tahun 2019 triwulan ke 1 sebesar Rp. 11.255.645.000.000 (Rp. 11,2 triliun) dan penjualan bersih pada PT Indofood CBP Sukses Makmur Tbk selama tahun 2010-2019 terendah terjadi pada tahun 2010 triwulan ke 1 sebesar Rp. 4.336.503.000.000 (Rp. 4,3 triliun). Hal ini sejalan dengan teori yang dipaparkan oleh (Mulyadi, 2015), yaitu "Penjualan bersih adalah Penjualan (pada nilai faktur) dikurangi dengan pengembalian, pengurangan harga, biaya transport yang dibayar untuk langganan dan potongan penjualan yang diambil". Penjualan bersih yang diakui oleh PT Indofood CBP Sukses Makmur Tbk merupakan jumlah total penjualan bersih yang ditambahkan dari penjualan kepada pelanggan eksternal dan penjualan antar segmen.

\section{Pengaruh Biaya Bahan Baku terhadap Penjualan Bersih pada PT Indofood CBP Sukses Makmur Tbk}

Berdasarkan dari hasil perhitungan analisis uji $\mathrm{t}$ dan ditampilkan dalam gambar dan tabel diatas, dapat diketahui nilai thitung sebesar 23,918. Jika dikaitkan dengan nilai ttabel, harus diketahui nilai derajat kebebasannya (df). Sehingga derajat kebebasan $(\mathrm{df})=$ n-k (40-2) sebesar 38 dan didapatkan ttabel sebesar 1,684. Berdasarkan hal tersebut, dapat diketahui thitung 23,918 > ttabel 1,684 dan jika dilihat dari tabel analisis uji $t$ (tabel 4.5), maka dapat diketahui angka signifikansi sebesar 0,000, dimana 0,000 <0,05 yang berarti terdapat pengaruh yang signifikan antara biaya bahan baku terhadap penjualan bersih pada PT Indofood CBP Sukses Makmur Tbk. Sehingga dapat disimpulkan bahwa Ha diterima dan Ho ditolak, yang berarti terdapat pengaruh positif yang signifikan antara biaya bahan baku terhadap penjualan bersih pada PT Indofood CBP Sukses Makmur Tbk.

Juga sejalan dengan penelitian-penelitian sebelumnya yang digunakan dalam penelitian ini, salah satunya penelitian yang dilakukan oleh (Wulandari, 2015) yang berjudul Pengaruh Biaya Produksi Terhadap Hasil Penjualan Pupuk Petroganik Pada CV. Ijo Ngawi dengan hasil menunjukkan bahwa biaya bahan baku berpengaruh positif dan signifikan terhadap hasil penjualan pupuk petroganik pada CV Ijo Ngawi. Hal tersebut juga sejalan dengan pendapat yang disampaikan oleh Sugiarti (2018) menjelaskan tentang 
kaitannya biaya bahan baku dengan penjualan menurutnya secara garis besar biaya. "Biaya bahan baku dan biaya tenaga kerja langsung merupakan dua komponen utama perusahaan dalam menjalankan usahanya. Dua komponen tersebut dalam hal bisnis sangat erat kaitannya dengan penjualan dan laba yang didapatkan oleh perusahaan". Jika dilihat dari keadaan biaya bahan baku dan penjualan bersih yang ada di PT Indofood CBP Sukses Makmur Tbk yang setiap tahunnya selalu berfluktuasi mengalami kenaikan dan penurunan hal tersebut ternyata saling mempengaruhi antara biaya bahan baku dan penjualan bersih di PT Indofood CBP Sukses Makmur Tbk. Dalam hal ini dapat disimpulkan bahwa biaya bahan baku merupakan komponen utama dalam pembuatan produk, maka hal tersebut berpengaruh dalam peningkatan penjualan. Karena jika tidak ada bahan baku maka tidak akan ada produk yang akan dijual oleh perusahaan.

\section{KESIMPULAN}

Dari analisis yang telah dilakukan di bab sebelumnya, diperoleh hasil mengenai pengaruh biaya bahan baku terhadap penjualan bersih pada PT Indofood CBP Sukses Makmur Tbk, berikut merupakan kesimpulan terkait hal tersebut, yaitu:

1. Biaya bahan baku yang dikeluarkan oleh PT Indofood CBP Sukses Makmur Tbk mengalami kenaikan dan penurunan dari tahun ke tahun per triwulan dari periode 2010-2019. Selama periode tersebut PT Indofood CBP Sukses Makmur Tbk paling besar terjadi pada tahun 2019 triwulan ke 1 sebesar Rp. 5.822.811.000.000 (5,8 Triliun Rupiah) dan pengeluaran biaya bahan baku pada PT Indofood CBP Sukses Makmur Tbk selama tahun 2010-2019 terendah terjadi pada tahun 2010 triwulan ke 4 sebesar Rp. 2.6333.277.000.000 (2,6 Triliun Rupiah).

2. Penjualan bersih yang diperoleh oleh PT Indofood CBP Sukses Makmur Tbk selama tahun 2010-2019 per triwulannya mengalami kenaikan dan penurunan dari tahun ke tahun. Penjualan bersih yang diperoleh PT Indofood CBP Sukses Makmur Tbk paling besar terjadi pada tahun 2019 triwulan ke 1 sebesar Rp. 11.255.645.000.000 (11,2 Triliun Rupiah) dan penjualan bersih pada PT Indofood CBP Sukses Makmur Tbk selama tahun 2010-2019 terendah terjadi pada tahun 2010 triwulan ke 1 sebesar Rp. 4.336.503.000.000 (4,3 Triliun Rupiah).

3. Berdasarkan hasil uji yang telah dilakukan sebelumnya, didapatkan hasil dalam uji $t$ yang menghasilkan bahwa nilai thitung $>$ ttabel. Yang berarti Ha diterima dan Ho ditolak. Sehingga diperoleh kesimpulan dalam penelitian ini terdapat pengaruh positif yang signifikan antara biaya bahan baku terhadap penjualan bersih pada PT Indofood CBP Sukses Makmur Tbk. Hal tersebut juga sejalan dengan pendapat yang disampaikan oleh Sugiarti (2018) menjelaskan tentang kaitannya biaya bahan baku dengan penjualan menurutnya secara garis besar biaya. "Biaya bahan baku dan biaya tenaga kerja langsung merupakan dua komponen utama perusahaan dalam menjalankan usahanya. Dua komponen tersebut dalam hal bisnis sangat erat kaitannya dengan penjualan dan laba yang didapatkan oleh perusahaan". Jika dilihat dari keadaan biaya bahan baku dan penjualan bersih yang ada di PT Indofood CBP Sukses Makmur Tbk yang setiap tahunnya selalu berfluktuasi mengalami kenaikan dan penurunan hal tersebut ternyata saling mempengaruhi antara biaya bahan baku dan penjualan bersih di PT Indofood CBP Sukses Makmur Tbk. Dalam hal ini dapat disimpulkan bahwa biaya bahan baku merupakan komponen utama dalam pembuatan produk, maka hal tersebut berpengaruh dalam peningkatan penjualan. Karena jika tidak ada bahan baku maka tidak akan ada produk yang akan dijual oleh perusahaan.

\section{DAFTAR PUSTAKA}

Ayuningtyas, D. (2019, October 31). Meski Laba ICBP Naik 12\% di Q3, Bisnis 
Minuman Malah Tekor! Cnbcindonesia.Com. Retrieved from https://www.cnbcindonesia.com/market/20191031101925-17-111562/meski-labaicbp-naik-12-di-q3-bisnis-minuman-malah-tekor

Dirgantara, H. (2020, May 14). Penjualan ekspor anjlok, tapi laba bersih Mayora Indah (MYOR) naik di kuartal I-2020. KONTAN.CO.ID. Retrieved from https://investasi.kontan.co.id/news/penjualan-ekspor-anjlok-tapi-laba-bersihmayora-indah-myor-naik-di-kuartal-i-2020

Hartanti. (2016). Pengaruh Biaya Bahan Baku Terhadap Penjualan Pada PT Shindengen Indonesia. Moneter, III(1), 83-99.

Moheb-Alizadeh, H., \& Handfield, R. (2018). The impact of raw materials price volatility on cost of goods sold (COGS) for product manufacturing. IEEE Transactions on Engineering Management, 65(3), 460-473. doi: 10.1109/TEM.2018.2796447

Sugiarti. (2018). Pengaruh Biaya Bahan Baku Dan Biaya Tenaga Kerja Langsung Terhadap Penjualan Bersih Pada Pt Mustika Ratu Tbk. Jurnal Akrab Juara, volume $3 N, 10$.

Sugiyono. (2019). Metode Penelitian Pendidikan (M. . Dr. Apri Nuryanto, S.Pd., S.T. (ed.); 3rd ed.). Bandung: ALFABETA, CV.

Wulandari, I. S. (2015). Pengaruh Biaya Produksi Terhadap Hasil Penjualan Pupuk Petroganik Pada CV. Ijo Ngawi. The 6th FIPA (Forum Ilmiah Pendidikan Akuntansi). 